Linguista: Jurnal Ilmiah Bahasa, Sastra, dan Pembelajarannya

Vol.3, No.2, Desember 2019, hal 80-90

ISSN (print): 2579-8944; ISSN (online): 2579-9037

Avaliable online at: http://e-journal.unipma.ac.id/index.php/linguista

\title{
Pengaruh Penggunaan Metode SQ3R dan Motivasi Belajar terhadap Kemampuan Memahami Bacaan SIswa Kelas IV Madrasah Ibtidaiyah Se-Kecamatan Sawahan
}

\author{
Yeti Nur Setyowati \\ MIN 2 Madiun, Jl. Kenanga No.2, Madiun, Indonesia \\ e-mail: yetinursetyowati@gmail.com
}

\begin{abstract}
Abstrak
Tujuan dalam penelitian ini adalah: 1) Untuk mengetahui pengaruh penggunaan metode SQ3R terhadap kemampuan memahami bacaan; 2) Untuk mengetahui pengaruh motivasi belajar siswa terhadap kemampuan memahami bacaan; 3) Untuk mengetahui pengaruh penggunaan metode pembelajaran SQ3R dan motivasi belajar terhadap kemampuan memahami bacaan. Sampel dalam peneletian ini adalah siswa kelas IV Madrasah Ibtidaiyah di Kecamatan Sawahan Kabupaten Madiun. Penelitian ini menggunakan metode penelitian Kuantitatif. Data yang digunakan adalah data Primer dan Sekunder. Teknik pengumpulan data yang digunakan adalah Dokumentasi, Kuesioner dan Tes. Teknik analisis data yang digunakan adalah analisis data secara deskriptif dan analisis data secara Inferensial dengan menggunakan teknik analisis of variance (ANOVA) dalam program SPSS. Hasil analisis menunjukkan: 1). Ada pengaruh penggunaan metode SQ3R terhadap kemampuan memahami bacaan, dengan nilai $F$ hitung lebih kecil dari $F$ tabel $(0,001<0,05)$. 2). Ada pengaruh tinggi rendah motivasi belajar siswa terhadap kemampuan memahami bacaan, dengan nilai $F$ hitung lebih kecil dari $F$ tabel $(0,002<0,05)$. 3). Ada pengaruh penggunaan metode pembelajaran SQ3R dan motivasi belajar terhadap kemampuan memahami bacaan, dengan nilai $F$ hitung lebih kecil dari $F$ tabel $(0,008<0,05)$. Dengan demikian dapat disimpulkan bahwa ada pengaruh penggunaan metode SQ3R dan moviasi belajar baik secara parsial maupun secara bersama-sama terhadap kemampuan memahami bacaan, pada siswa kelas 4 Madrasah Ibtidaiyah di Kecamatan Sawahan Kabupaten Madiun.
\end{abstract}

Kata kunci: Metode SQ3R; Motivasi Belajar; Membaca Pemahaman.

\section{The Effect of SQ3R Method and Learning Motivation Towards Ability to Understand Reading}

\begin{abstract}
The aims of this research are: 1) Knowing the effect of SQ3R method towards ability to understand reading; 2) Knowing the effect of students learning motivation towards ability to understand; 3) Knowing the effect of SQ3R method and learning motivation towards ability to understand reading. The sample in this research was the fourth grade students of Madrasah Ibtidaiyah, Sawahan district, Madiun Regency. This research used quantitative method. The data were primary and secondary. The technique of data collection used was documentation, questionnaire and test. Data analysis technique used was descriptive analysis and Inferential data analysis with Analysis of Variance (ANOVA) on SPSS. The results of the analysis show that: 1). There is an effect of SQ3R method towards ability to understand reading, with value of $F$ count was smaller than $F$ table $(0.001<0.05)$. 2). There is an effect of learning motivation towards ability to understand reading, with value of $F$ theory was smaller than $F$ table $(0.002<0.05)$. 3).
\end{abstract}


There is an effect of SQ3R method and learning motivation towards ability to understand reading, with value of $F$ theory was smaller than $F$ table $(0.008<0.0) 5$. Therefore, it can be concluded that there is an effect of SQ3R method and learning motivation partially or universal towards the fourth grade students' reading ability of Madrasah Ibtidaiyah, Sawahan district, Madiun Regency.

Keywords: SQ3R; Motivation; ability to understand reading.

\section{Pendahuluan}

Kemampuan membaca merupakan suatu kemampuan untuk memahami informasi atau wacana yang disampaikan pihak lain melalui tulisan. Menurut Hodgos dalam Tarigan (2008: 7), membaca merupakan suatu proses yang dilakukan serta dipergunakan oleh pembaca untuk memperoleh pesan yang hendak disampaikan oleh penulis melalui media kata-kata/bahasa tulis. Keterampilan membaca diperlukan untuk dapat memahami pesan yang disampaikan oleh penulis melalui media kata-kata atau bahasa tulis. Jadi, keterampilan membaca bisa dikatakan sebagai ciri dari manusia yang terpelajar atau bangsa yang terpelajar. Dalam masyarakat yang berteknologi modern, melek huruf merupakan modal vital agar dapat mengikuti perkembangan dan kemajuan zaman. Sehingga dapat pula dikatakan bahwa kemampuan membaca merupakan salah satu tujuan fundamental dalam capaian pendidikan di tingkat dasar. Hampir sebagian besar aktivitas belajar merupakan kegiatan membaca. Bahkan aktivitas membaca dapat diibaratkan sebagai pembuka jendela dunia yang mempunyai peran besar untuk meningkatkan potensi diri. Hal ini senada dengan yang diungkapkan oleh Rahim (2008:1) bahwa "kemampuan membaca merupakan tuntutan realitas kehidupan sehari-hari manusia". Oleh karena itu, keterampilan membaca merupakan keterampilan dasar berbahasa yang perlu dimiliki oleh setiap anak.

Membaca pada hakikatnya adalah suatu yang rumit yang melibatkan banyak hal, tidak hanya sekedar melafalkan tulisan, tetapi juga melibatkan aktivitas visual, berpikir, psikolinguistik, dan metakognitif (Rahim, 2008:2) Dari pernyataan tersebut dapat disimpulkan bahwa membaca memerlukan motivasi yang tinggi dan aktivitas otak bukan hanya sekedar gerakan mata. Membaca memerlukan konsentrasi yang tinggi untuk menemukan makna bacaan. Keterampilan berbahasa mencakup empat hal, yaitu menyimak, berbicara, membaca, dan menulis. Tarigan (2008:1) mengatakan bahwa menyimak dan berbicara dipelajari sebelum masuksekolah, sedangkan membaca dan menulis dipelajari di sekolah. Hal tersebut sejalan dengan tahap perkembangan perkembangan anak, yaitu mendengar. Kemudian setelah anak mendengar/ menyimak bahasa anak mulai belajar berbicara, dan kemudian anak belajar membaca dan menulis di sekolah.

Anak mulai diajarkan membaca ketika mereka duduk di bangku pendidikan formal. Hampir seluruh kegiatan pembelajaran adalah membaca. Namun demikian ternyata membaca belum mampu menjadi budaya. Tidak sedikit anak yang malas membaca dan menganggap membaca merupakan kegiatan yang membosankan. Akibatnya pembelajaran menjadi terhambat dan tidak tuntas. Dengan demikian keterampilan membaca merupakan kemampuan yang mutlak dikuasai oleh semua individu yang ingin maju (melek huruf). Tanpa beranjak dari tempat duduk kita mampu 
melihat dunia dengan membaca. Bukan hanya pengetahuan, membaca juga mampu memberikan hiburan bagi pembacanya, sebagai contoh membaca karya sastra.

Berdasarkan Permendiknas Nomor 23 Tahun 2006, dimana pengajaran bahasa Indonesia di SD dengan fokus keterampilan membaca meliputi "menggunakan berbagai jenis membaca untuk memahami wacana berupa petunjuk teks panjang, dan berbagai karya sastra untuk anak berbentuk puisi, dongeng, pantun, percakapan, cerita, dan drama". Keterampilan membaca tersebut difokuskan pada kemampuan memahami makna/isi bacaan. Dengan demikian jelas bahwa kemampuan membaca siswa di tingkat dasar menjadi kunci keberhasilan siswa di jenjang selanjutnya.

Namun demikian ternyata kegiatan membaca belum mampu merebut hati setiap orang. Bagi sebagian orang kegiatan membaca dianggap sebagai hal yang membosankan dan kurang manfaat. Perpustakaan sekolah terkesan tanpa pengunjung kecuali ketika ada tugas yang mengharuskan mereka membaca buku di perpustakaan. Jumlah pengunjung toko buku yang sangat sedikit dibandingkan pengunjung pusat perbelanjaan. Kondisi yang demikian umum terjadi dan bukan tanpa sebab. Banyak faktor yang menyebabkan kurangnya minat baca pada setiap individu. Peneliti melakukan observasi saat KBM pada siswa yang ada di MI Al Hikmah terutama kelas IV sebagai fokus penelitian, kondisi yang terjadi ketika mereka ditugaskan membaca terkesan enggan melakukannya. Tampak betapa bosan mereka melakukan aktifitas membaca. Padahal sebagian besar aktifitas pembelajaran di sekolah berhubungan dengan buku yang harus dibaca. Ditambah lagi kasus anak yang kurang mampu membaca dengan lancar. Dengan demikian sudah barang tentu anak yang kurang mampu membaca akan mengalami kesulitan dalam belajar. Sebaliknya anak yang memiliki keterampilan membaca yang lebih baik akan lebih mampu menyesuaikan perkembangan di berbagai bidang dalam kehidupan mereka.

Berdasarkan informasi yang didapat melalui pengamatan peneliti di kelas, kegiatan pembelajaran tematik dalam kurikulum 2013 didominasi oleh kegiatan membaca. Menurut beberapa siswa, proses pembelajaran menjadi membosankan dan membuat mengantuk. Hal tersebut menunjukkan minat siswa yang kurang terhadap kegiatan membaca. Salah satu keterampilan membaca yang diajarkan di kelas IV adalah keterampilan membaca intensif. Menurut Tarigan (2008:12), "keterampilan membaca intensif yaitu membaca dengan penuh pemahaman untuk menemukan ide-ide pokok pada tiap-tiap paragraf, pemahaman ide-ide naskah dari ide pokok sampai pada ide-ide penjelas, dari hal-hal yang rinci sampai ke relung-relungnya".

Kegagalan pembelajaran membaca di sekolah merupakan kegagalan awal yang akan berkelanjutan apabila masalah ini tidak diatasi. Masalah utama dalam pembelajaran membaca tidak hanya terletak pada siswa, namun guru juga memegang peranan penting. Berdasarkan kondisi yang ada di lapangan, pembelajaran membaca hanya berhenti pada bisa atau tidaknya anak menggabungkan huruf-huruf menjadi kata dan kalimat. Akibatnya mereka hanya bisa membaca saja tanpa mampu memahami maknanya. Sebagian guru beranggapan bahwa kemampuan memahami bacaan akan berjalan seiring kemampuan membaca siswa. Namun pada kenyataannya pemahaman suatu bacaan menjadi permasalahan yang mendasar. Selaku Guru kelas IV, peneliti menemukan bahwa kemampuan membaca siswa kelas IV MI Al Hikmah Rejosari Sawahan sangat rendah. Dari 20 siswa hanya 4 siswa yang mampu menjawab soal-soal pemahaman bacaan. Sedangkan 16 siswa atau 80\% siswa mengalami kesulitan 
memahami bacaan sehingga tidak mampu menjawab soal-soal pemahaman bacaan yang diberikan guru. Hal ini menunjukkan bahwa kelemahan kemampuan membaca membuat kegiatan belajar mengajar menjadi terhambat dan tidak sesuai dengan target yang dikehendaki. Siswa seperti tidak memiliki motivasi ketika diberi materi tematik yang cenderung membaca. Salah satu keluhan siswa yaitu teks bacaan yang terlalu panjang. Siswa juga tidak suka dengan teks bacaan yang pada akhirnya hanya akan mencari ide pokok.

Dari data tersebut, maka dapat digali permasalahan yang menjadi sebab lemahnya keterampilan membaca yang berujung pada kurangnya pemahaman siswa dalam memahami suatu teks bacaan. Hal ini disebabkan kurangnya minat siswa dalam membaca yang dipengaruhi oleh gaya mengajar guru, metode pembelajaran yang monoton dan tidak adanya penggunaan media belajar yang menarik serta penggunaan teknik membaca yang kurang disesuaikan dengan keterampilan membaca yang akan diajarkan khususnya di kelas IV. Selain itu motivasi belajar siswa tidak kalah pentingnya dalam meningkatkan kemauan siswa mencapai tujuan belajar.

Belajar merupakan proses kegiatan untuk mengubah tingkah laku dipengaruhi oleh banyak faktor. Baik faktor ekstern (dari luar) maupun faktor intern (dari dalam). Salah satu faktor ekstern adalah metode pembelajaran. Memahami sebuah bacaan menjadi kunci keberhasilan pembelajaran. Membelajarkan membaca memerlukan metode untuk mencapai tujuan yang dicapai. Dalman (2014:189) mendefinisikan SQ3R sebagai salah satu teknik membaca untuk memahami isi bacaan. Hal tersebut sejalan dengan pendapat Soedarso (2004:59) berpendapat bahwa melalui tahapan SQ3R akan lebih mudah memahami dan menguasai bacaan, serta dapat mengingat bacaan lebih lama. Dalam hal ini peneliti mencoba menerapkan metode SQ3R untuk pembelajaran kemampuan memahami bacaan.

Metode SQ3R merupakan salah satu metode membaca yang dapat diterapkan dalam pembelajaran pemahaman bacaan di sekolah. Memahami bacaan menjadi kunci untuk memperoleh informasi sebanyak-banyaknya. Oleh karena itu, pemilihan metode membaca sangat diperlukan untuk meningkatkan kemampuan memahami bacaan pada siswa. Metode SQ3R mencakup lima langkah sebagai berikut ini: 1) Survey (penelaahan pendahuluan); 2) Question (bertanya); 3) Read (baca); 4) Recite (mengutarakan kembali). Sehubungan dengan proses interaksi belajar, di samping faktor ekstern tersebut juga melibatkan faktor intern khususnya faktor-faktor psikologis merupakan faktor yang sangat berperan. Menurut Thomas F. Staton dalam Sardiman (2012: 39-40) faktor psikologis meliputi: (1) motivasi; (2) konsentrasi; (3) reaksi; (4) organisasi; (5) pemahaman; (6) ulangan. Dari penjelasan di atas tampak bahwa motivasi merupakan faktor intern psikologi yang prinsip. Dalam proses belajar dan pembelajaran. Motivasi dalam hal ini meliputi: (1) mengetahui apa yang akan dipelajari; (2) memahami mengapa hal tersebut dipelajari. Kesimpulannya, motivasi belajar merupakan sesuatu yang mendorong, menggerakan dan mengarahkan siswa dalam belajar. Motivasi belajar akan merubah perilaku siswa di sekolah. Bila pendidik membangkitkan motivasi belajar anak didik, maka meraka akan memperkuat respon yang telah dipelajari.

\section{Metode Penelitian}

Penelitian ini menggunakan metode penelitian Kuantitatif. Data yang digunakan adalah data Primer dan Sekunder. Teknik pengumpulan data yang digunakan adalah 
Dokumentasi, Kuesioner/Angket dan Tes. Untuk menguji keabsahan data peneliti menguji dengan uji test validitas dan reliabilitas. Sedangkan sampel dalam penelitian ini adalah sampel total dengan jumlah 140 siswa dimana 70 siswa dengan metode SQ3R dan \& 70 siswa non SQ3R yang berasal dari siswa kelas IV Madrasah Ibtidaiyah seKecamatan Sawahan yakni: MI AI Hikmah sejumlah 20 orang; MI PSM Bakur sejumlah 36 orang; MI Hidayatul Sibyan sejumlah 34 siswa; dan MI Miftahul Huda sejumlah 50 siswa. Teknik analisis data yang digunakan adalah analisis data secara deskriptif untuk menyajikan data secara umum, yaitu data-data yang berhubungan dengan pemahaman bacaan dan motivasi belajar siswa dan analisis data secara Inferensial untuk menganalisis data penelitian dengan menggunakan teknik analisis of variance (ANOVA) dalam program SPSS.

\section{Hasil dan Pembahasan}

Hasil penelitian akan dilaporkan melalui dua tahap, yaitu (1) secara deskriptif dan (2) secara inferensial. Laporan secara deskriptif dilengkapi dengan tabel. Sedangkan laporan secara inferensial menyajikan hasil analisisi statistik dengan Anava dua jalan. Berdasarkan variabel-variabelnya, maka hasil penelitian ini dilaporkan sebagai berikut.

\section{A. Deskripsi Hasil}

Analisis deskriptif yang peneliti lakukan untuk mengetahui pengaruh metode belajar SQ3R (X1) dan motivasi belajar siswa (X2) terhadap kemampuan memahami bacaan siswa $(Y)$. Untuk mengetahui perbedaan kemampuan memahami bacaan siswa dengan metode SQ3R (vaiabel X1) dan non Metode SQ3R, dapat dilihat dalam tabel berikut:

Tabel 1. Deskripsi data kemampuan memahami bacaan siswa dengan metode SQ3R

\begin{tabular}{|c|c|c|c|c|c|}
\hline & \multirow{14}{*}{$\begin{array}{l}\text { Metode Pembelaiaran } \\
\text { SQ3R }\end{array}$} & & & Statistic & Sid Error. \\
\hline \multirow[t]{26}{*}{ Pemahaman } & & \multicolumn{2}{|l|}{ Maan } & 80,76 & 1,316 \\
\hline & & \multirow{2}{*}{$\begin{array}{l}95 \% \text { Confidence } \\
\text { Interv al for Mean }\end{array}$} & \multirow{12}{*}{$\begin{array}{l}\text { Lower Bound } \\
\text { Upper Bound }\end{array}$} & 78,13 & \\
\hline & & & & 83,38 & \\
\hline & & $5 \%$ Trimmed Mean & & 80,84 & \\
\hline & & Median & & 80,00 & \\
\hline & & Variance & & 121,259 & \\
\hline & & Std. Deviation & & 11,012 & \\
\hline & & Mnimum & & 60 & \\
\hline & & Maximum & & 100 & \\
\hline & & Range & & 40 & \\
\hline & & Interquartie Range & & 17 & \\
\hline & & Skewness & &,- 045 & .287 \\
\hline & & Kurtosis & &,- 912 & 566 \\
\hline & \multirow[t]{13}{*}{ Non SQ3R } & Maan & & 74,50 & 1,388 \\
\hline & & \multirow{2}{*}{$\begin{array}{l}95 \% \text { Confidence } \\
\text { Interv al for Mean }\end{array}$} & Lower Bound & 71,73 & \\
\hline & & & Upper Bound & 77,27 & \\
\hline & & $5 \%$ Trimmed Mean & & 74,25 & \\
\hline & & Median & & 73,00 & \\
\hline & & Variance & & 134,891 & \\
\hline & & Std. Deviation & & 11,614 & \\
\hline & & Mnimum & & 53 & \\
\hline & & Maximum & & 100 & \\
\hline & & Range & & 47 & \\
\hline & & Interquartie Range & & 16 & \\
\hline & & Skewness & & .251 & 287 \\
\hline & & Kurtosis & & -533 & ,566 \\
\hline
\end{tabular}


Berdasarkan tabel di 1 menunjukkan bahwa: Nilai-nilai yang didapatkan yaitu: $\mathrm{n}$ sebanyak 70 ; nilai minimal $(\mathrm{min})$ sebesar 60 ; nilai maksimal (max) sebesar 100; rata-rata $(\mathrm{Mn})$ 80.76; standar deviasi $(\mathrm{SD})$ sebesar 11.01; harga pertengahan (Me) sebesar 80.00; harga modus (Mo) sebesar 80.00. Setelah dilakukan analisis deskriptif, nilai-nilai yang didapatkan yaitu: $n$ sebanyak 70 ; nilai minimal (min) sebesar 53; nilai maksimal ( $\max$ ) sebesar 100; rata-rata $(\mathrm{Mn})$ 74.50; standart deviasi (SD) sebesar 11.614; harga pertengahan (Me) sebesar 73.00; harga modus (Mo) sebesar 77.00. Berdasarkan data tersebut, nampak bahwa rata2 nilai siswa dengan menggunakan metode SQ3R sebesar 80,76 lebih tinggi dibandingkan dengan non metode SQ3R yakni hanya memiliki nilai rata-rata sebesar 74,50. Dengan demikian dapat dikatakan bahwa dengan metode SQ3R, kemampuan memahami bacaan siswa lebih baik dibandingkan dengan non metode SQ3R. Selanjutnya, untuk mengetahui perbedaan kemampuan memahami bacaan dengan motivasi belajar tinggi dan rendah dapa dilihat dalam tabel berikut:

Tabel 2. Deskripsi kemampuan memahami bacaan dengan motivasi belajar tinggi dan rendah

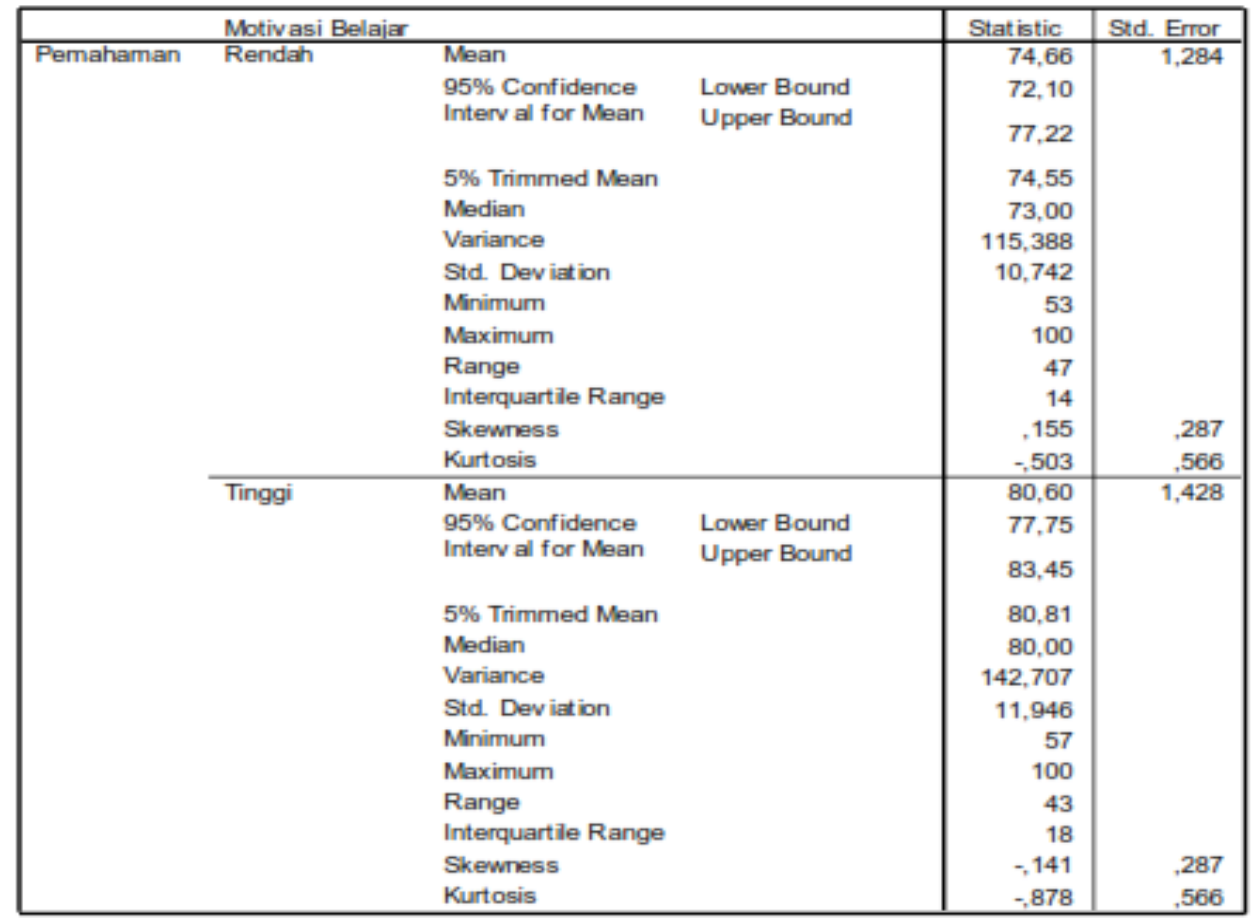

Berdasarkan tabel 2, menunjukkan bahwa: Setelah dilakukan analisis deskriptif, nilai-nilai yang didapatkan yaitu: $n$ sebanyak 70 ; nilai minimal (min) sebesar 60; nilai maksimal ( $\max$ ) sebesar 100; rata-rata $(\mathrm{Mn})$ 80.60; standart deviasi (SD) sebesar 11.01; harga pertengahan (Me) sebesar 80.00; harga modus (Mo) sebesar 77.00. Setelah dilakukan analisis deskriptif, nilai-nilai yang didapatkan yaitu: $n$ sebanyak 70; nilai minimal ( $\min$ ) sebesar 53; nilai maksimal (max) sebesar 100 ; rata-rata $(\mathrm{Mn})$ 74.66; standart deviasi (SD) sebesar 10.742; harga pertengahan $(\mathrm{Me})$ sebesar 73.00; harga modus (Mo) sebesar 70.00. Berdasarkan data tersebut, nampak bahwa nilai siswa dengan motivasi belajar yang tinggi mendapatkan nilai rata-rata sebesar 80,60 lebih tinggi dibandingkan dengan nilai siswa yang memiliki motivasi belajar rendah, yakni hanya memiliki nilai rata-rata sebesar 74,66 . Dengan demikian dapat dikatakan bahwa siswa dengan motivasi belajar yang tinggi memiliki 
kemampuan memahami bacaan lebih baik dibandingkan dengan siswa yang memiliki motivasi belajar rendah.

Sedangkan untuk mengetahui perbedaan metode belajar SQ3R (X1) dan motivasi belajar (X2) siswa terhadap kemampuan memahami bacaan siswa $(\mathrm{Y})$, disajikan dalam tabel berikut:

Tabel 3. Deskripsi perbedaan metode belajar SQ3R (X1)/Non SQ3R dan motivasi belajar (X2) siswa tinggi/rendah terhadap kemampuan memahami bacaan siswa $(\mathrm{Y})$

\begin{tabular}{|ll|r|r|r|}
\hline Metode Pembelajaran & Motivasi Belajar & \multicolumn{1}{|c|}{ Mean } & Sid. Deviation & N \\
\hline SQ3R & Rendah & 75,29 & 9,889 & 34 \\
& Tinggi & 85,92 & 9,512 & 36 \\
& Total & 80,76 & 11,012 & 70 \\
\hline Non SQ3R & Rendah & 74,06 & 11,598 & 36 \\
& Tinggi & 74,97 & 11,787 & 34 \\
& Total & 74,50 & 11,614 & 70 \\
\hline Total & Rendah & 74,66 & 10,742 & 70 \\
& Tinggi & 80,60 & 11,946 & 70 \\
& Total & 77,63 & 11,705 & 140 \\
\hline
\end{tabular}

Kemampuan pemahaman bacaan pada siswa dengan metode SQ3R dan motivasi belajar tinggi. Setelah dilakukan analisis deskriptif, nilai-nilai yang didapatkan yaitu: $n$ sebanyak 36; nilai minimal ( $\min$ ) sebesar 67.00; nilai maksimal (max) sebesar 100; rata-rata $(\mathrm{mn})$ 85.92; standart deviasi $(\mathrm{sd})$ sebesar 9.512. Setelah dilakukan analisis deskriptif, nilai-nilai yang didapatkan yaitu: $\mathrm{n}$ sebanyak 34; nilai minimal $(\min )$ sebesar 60.00; nilai maksimal ( $\max$ ) sebesar 100; rata-rata (mn) 75.29; standart deviasi (sd) sebesar 9.889. Setelah dilakukan analisis deskriptif, nilai-nilai yang didapatkan yaitu: $n$ sebanyak 34 ; nilai minimal (min) sebesar 57.00; nilai maksimal $(\max )$ sebesar 100; rata-rata $(\mathrm{mn}) 74.97$; standart deviasi (sd) sebesar 11.707. Setelah dilakukan analisis deskriptif, nilai-nilai yang didapatkan yaitu: $\mathrm{n}$ sebanyak 36 ; nilai minimal $(\mathrm{min})$ sebesar 53.00 ; nilai maksimal (max) sebesar 100; rata-rata $(\mathrm{mn})$ 74.06; standart deviasi (sd) sebesar 11.598.

Berdasarkan data di atas, nampak bahwa kemampuan pemahaman bacaan pada siswa dengan metode SQ3R dan motivasi belajar tinggi memiliki nilai ratarata paling tinggi yakni sebesar 85,92 . Kemampuan pemahaman bacaan pada siswa dengan metode SQ3R dan motivasi belajar rendah memiliki nilai rata-rata sebesar 75,29. Kemampuan pemahaman bacaan pada siswa tanpa metode SQ3R dan motivasi belajar tinggi memiliki nilai rata-rata sebesar 74,97. Sedangkan kemampuan pemahaman bacaan pada siswa tanpa metode SQ3R dan motivasi belajar rendah memiliki nilai rata-rata sebesar 74,06.

Dengan demikian dapat dikatakan bahwa siswa dengan metode SQ3R dan motivasi belajar tinggi memiliki kemampuan pemahaman bacaan lebih baik dibandingkan dengan metode SQ3R dan motivasi rendah, non metode SQ3R dan motivasi tinggi maupun non metode SQ3R dan motivasi rendah. Namun dari data tersebut dapat kita temukan bahwa metode SQ3R memiliki pengaruh yang lebih besar dibandingkan dengan pengaruh motivasi tinggi terhadap kemampuan memahami bacaan siswa. Dimana nilai rata-rata siswa 75.29 dengan SQ3R masih lebih tinggi meskipun motivasi belajar siswa rendah sedangkan nilai rata-rata siswa dengan motivasi tinggi hanya 74.97 tanpa metode SQ3R. 


\section{B. Analisis data secara Inferensial dengan menggunakan teknik analisis of variance (ANOVA) dalam program SPSS 20.}

Setelah dilakukan analisis statistik dengan program SPSS, diperoleh hasil sebagai berikut.

Tabel 4. Hasil Analisis dengan teknik ANOVA

Tests of Between-Subjects Effects

Dependent Variable: Pemahaman
\begin{tabular}{|l|r|r|r|r|r|}
\hline Source & $\begin{array}{c}\text { Type III Sum } \\
\text { of Squares }\end{array}$ & df & Mean Square & \multicolumn{1}{c|}{ F } & \multicolumn{1}{c|}{ Sig. } \\
\hline Corrected Model & $3358,017^{a}$ & 3 & 1119,339 & 9,704 &, 000 \\
Intercept & 841473,348 & 1 & 841473,348 & 7295,391 &, 000 \\
Metode & 1298,012 & 1 & 1298,012 & 11,253 &, 001 \\
Motivasi & 1163,812 & 1 & 1163,812 & 10,090 &, 002 \\
Metode * Motiv asi & 823,891 & 1 & 823,891 & 7,143 &, 008 \\
Error & 15686,668 & 136 & 115,343 & & \\
Total & 862712,000 & 140 & & & \\
Corrected Total & 19044,686 & 139 & & & \\
\hline
\end{tabular}

a. $R$ Squared = ,176 (Adjusted R Squared $=, 158$ )

Berdasarkan hasil analisis statistik dengan teknik ANOVA menunjukkan bahwa:

1. Terdapat perbedaan kemampuan memahami bacaan antara siswa yang diajar dengan metode SQ3R dan siswa yang tidak diajar dengan menggunakan metode SQ3R.

Nilai $F$ hitung uji beda pemahaman antara kelompok metode SQ3R dengan metode Non SQ3R sebesar 11.253 dengan signifikansi sebesar 0,001. Karena harga signifikansi $0,001<0,05$, maka Ho di tolak dan Ha diterima. Jadi ada perbedaan yang signifikan pemahaman antara kelompok dengan pembelajaran SQ3R dibandingkan dengan pembelajaran dengan metode Non SQ3R.

Sedangkan berdasarkan Dengan demikian sejalan dengan pendapat Soedarso (2004:59) bahwa melalui tahapan SQ3R akan lebih mudah memahami dan menguasai bacaan, serta dapat mengingat bacaan lebih lama. Hal ini dikuatkan dengan hasil penelitian Dyahpuspita (2015) menyimpulkan bahwa kemampuan membaca pemahaman dengan metode SQ3R lebih tinggi daripada kemampuan membaca pemahaman dengan metode diskusi. Hal tersebut menunukkan keefektifan penggunaan metode SQ3R dalam pembelajaran pemahaman bacaan. Sedangkan menurut hasil penelitian Fitriani (2017) metode SQ3R dapat meningkatkan kemampuan mahasiswa dalam membaca pemahaman.

2. Terdapat perbedaan kemampuan memahami bacaan antara siswa dengan motivasi belajar tinggi dan motivasi belajar rendah.

Nilai $\mathrm{F}$ hitung uji beda pemahaman antara kelompok motivasi tinggi dengan motivasi rendah sebesar 10,090 dengan signifikansi sebesar 0,002. Karena harga signifikansi $0,002<0,05$, maka Ho ditolak dan Ha diterima. Dengan demikian dapat disimpulkan bahwa ada perbedaan yang signifikan pemahaman antara kelompok dengan motivasi Tinggi dibandingkan dengan motivasi rendah. Dengan demikian Sejalan dengan pendapat Sardiman (2001:73) yang mengemukaan bahwa, "motivasi dapat dikatakan sebagai keseluruhan daya penggerak di dalam diri siswa yang menimbulkan kegiatan belajar yang 
menjamin arah pada kegiatan belajar, sehingga tujuan yang dikehendaki oleh subjek belajar itu dapat tercapai". Dari beberapa penelitian menunjukkan bahwa motivasi berperan dalam aktivitas memahami bacaan siswa. Dalam penelitian Hidayah (2016) tentang hubungan antara motivasi belajar dan kemampuan membaca pemahaman menimpulkan bahwa terdapat hubungan yang positif dan signifikan antara motivasi belajar dan kemampuan membaca pemahaman siswa.

3. Interaksi antara penggunaan metode SQ3R dan motivasi belajar siswa dalam mempengaruhi kemampuan memahami bacaan siswa.

Nilai $F$ hitung uji beda pemahaman antara kelompok metode SQ3R dengan motivasi tinggi dan rendah serta metode Non SQ3R dengan motivasi tinggi dan rendah sebesar 7,143 dengan signifikansi sebesar 0,008. Karena harga signifikansi $0,008<0,05$, maka Ho ditolak dan Ha diterima. Dengan demikian dapat disimpulkan bahwa ada perbedaan yang signifikan pemahaman antara kelompok dengan pembelajaran SQ3R dengan motivasi tinggi dan rendah dibandingkan dengan pembelajaran dengan metode Non SQ3R dengan motivasi tinggi dan rendah. Hal ini memperkuat hasil penelitian Sidebang (2016) dalam tema penelitian tentang pengaruh strategi pembelajaran dan motivasi belajar terhadap kemampuan membaca pemahaman teks narasi siswa tahun 2016 menunjukkan bahwa terdapat interaksi antara strategi pembelajaran dan motivasi belajar dalam meningkatkan hasil belajar kemampuan membaca pemahaman teks narasi siswa Motivasi sangat berpengaruh pada kegiatan belajar siswa. Ada tidaknya motivasi seseorang individu untuk belajar sangat berpengaruh dalam proses aktivitas belajar itu sendiri.

\section{Kesimpulan}

Ada pengaruh penggunaan metode SQ3R terhadap kemampuan pemahaman bacaan siswa. Nilai $F$ hitung uji beda pemahaman antara kelompok metode SQ3R dengan metode Non SQ3R sebesar 11,253 dengan signifikansi sebesar 0,001<0,05, maka disimpulkan bahwa ada perbedaan yang signifikan pemahaman antara kelompok dengan pembelajaran SQ3R dibandingkan dengan pembelajaran dengan metode Non SQ3R. Ada pengaruh tinggi rendah motivasi belajar siswa terhadap kemampuan pemahaman bacaan siswa. Siswa dengan motivasi belajar tinggi mempunyai rerata nilai yang lebih tinggi daripada siswa dengan motivasi belajar rendah. Nilai F hitung uji beda pemahaman antara kelompok motivasi tinggi dengan motivasi rendah sebesar 10,090 dengan signifikansi sebesar 0,002 <0,05, maka disimpulkan bahwa ada perbedaan yang signifikan pemahaman antara kelompok dengan motivasi Tinggi dibandingkan dengan motivasi rendah. Ada pengaruh penggunaan metode membaca SQ3R dan Motivasi belajar terhadap kemampuan pemahaman bacaan siswa. Nilai F hitung uji beda pemahaman antara kelompok metode SQ3R dengan metode Non SQ3R sebesar 11,253 dengan signifikansi sebesar 0,001. Karena harga signifikansi 0,001<0,05, maka disimpulkan bahwa ada perbedaan yang signifikan pemahaman antara kelompok dengan pembelajaran SQ3R dibandingkan dengan pembelajaran dengan metode Non SQ3R. Berdasarkan analisis deskriptif menunjukkan bahwa pengaruh metode SQ3R lebih besar dibandingkan dengan pengaruh motivasi, dimana metode SQ3R dengan motivasi rendahpun dengan nilai rata-rata 75.29 masih lebih tinggi dibandingan dengan non SQ3R dengan motivasi tinggi nilai rata-rata 74,97 . 


\section{Daftar Pustaka}

Abidin. (Ed.). (2012). Pembelajaran Membaca Berbasis Pendidikan Karakter. Bandung: Refika Aditama.

Ahmad, S. (2010). Speed Reading Teknik dan Metode Membaca Cepat. Jogjakarta: A*Plus Books

Ahuja, A dan Ahuja. (2004). Membaca Secara Efektif dan Efisien. Jakarta: Kiblat Buku Utama.

Arikunto, S. (2010). Prosedur Penelitian. Jakarta: Rineka Cipta.

Brown, H. D. (2000). Teaching by Principles: An Interactive Approach to Language Pedagogy. White Plains: Addison Wesley Logman.

Brown, H. D. (2003). Language Assesment Principles and Classroom Practices. White Plains: Addison Wesley Logman.

Dalman, D (2014). Keterampilan Membaca. Jakarta: Rajawali Pers.

Dyahpuspita, N. (2005). Pengaruh Metode SQ3R Terhadap Kemampuan Membaca Siswa Kelas IV.2 SD Muhammadyah Mutihan Tahun Pelajaran 2014/2015. FKIP UNY.

Fitriani, D. (2017). Kemampuan Membaca Pemahaman Dengan Menggunakan Metode Survey, Question, Read, Recite, dan Review (SQ3R). Jurnal Pesona.Volume 3.

Hidayah, N. (2016). Terampil Jurnal Pendidikan dan Pembelajaran Dasar Volume 3 no 2. IAIN Raden Intan Lampung.

Margono, S. (2010). Metodologi Penelitian Pendidikan. Jakarta: Rineka Cipta

Nurgiyantoro, B. (2014), Penilaian Pembelajaran Bahasa Berbasis Kompetensi. Yogyakarta: BPFE

Purwanto, P. (2010). Metodologi Penelitian Kuantitatif untuk Psikologi dan Pendidikan. Yogyakarta: Pustaka Belajar

Putra, M.S, (2008). Menumbuhkan Minat Baca Sejak Dini. Jakarta:PT Macananjaya Cemerlang.

Rahim, F. (2008). Pengajaran Membaca di Sekolah Dasar. Jakarta: Bumi Aksara.

Schunk, Dalle H. Pintrich, Paul R. Meece, Judith L. Motivasi dalam Pendidikan: Teori, Penelitian, dan Aplikasi. (terjemahan Ellys Tjo. Jakarta Barat: Indeks. Buku asli diterbitkan tahun 2008

Saddono, K., dan Slamet, S. (2014). Pembelajaran Keterampilan Berbahasa Indonesia. Yogyakarta: Graha Ilmu.

Sarwiji, S. (2011). Model-model Asesmen dalam Pembelajaran. Surakarta: Yuma Pustaka.

Sidebang, R. (2016). Jurnal Tematik 6. University Quality Sumatra Utara.

Soedarso. (2004). Speed Reading: Sistem Membaca Cepat dan Efektif. Jakarta: Gramedia Pustaka Utama.

Tarigan, H.G. (2008). Membaca sebagai suatu keterampilan Berbahasa. Bandung: Angkasa. 
Tampubolon, D.P. (1987). Kemampuan Membaca: Teknik Membaca Efektif dan Efisien. Bandung: Angkasa. 